\title{
Effects of Climate Variability and Human Activities on Chesapeake Bay and the Implications for Ec osystem Restoration
}

\section{Introduction}

Chesapeake Bay, the Nation's largest and most productive estuary (fig. 1), faces complex environmental issues related to nutrients and oxygen, turbidity and sedimentation, toxic dinoflagellates, sea-level rise, and coastal erosion. The Chesapeake Bay Program (CBP) is a partnership among the Chesapeake Bay Commission, the Federal Government, the District of Columbia, and the States of Maryland, Virginia, and Pennsylvania. The CBP is working to preserve, restore, and protect the bay's living resources, vital habitats, and water quality, to protect human health, and to promote sound land-use policies in the watershed. The CBP began to set restoration goals for the ecosystem in the mid-1980's and is now refining current goals and setting new ones as part of a new bay agreement-Chesapeake 2000. As the CBP sets restoration goals for the next 10-20 years, it will be critical to understand the long-term changes of the bay ecosystem due to climate variability and the influence of past and future human activities.

For the past 4 years, the U.S. Geological Survey (USGS) has been engaged in research designed to provide objective scientific answers to questions about long-term changes in the bay ecosystem:

- What paleoecological and geochemical methods are best for documenting trends in the bay ecosystem?

- How does climate variability, including drought, affect the bay?

- What are historical trends in dissolved oxygen?

- What is the relationship between sedimentation and water clarity, and what is the effect of turbidity on living resources?

- How have past land-use changes affected bay habitats and living resources?

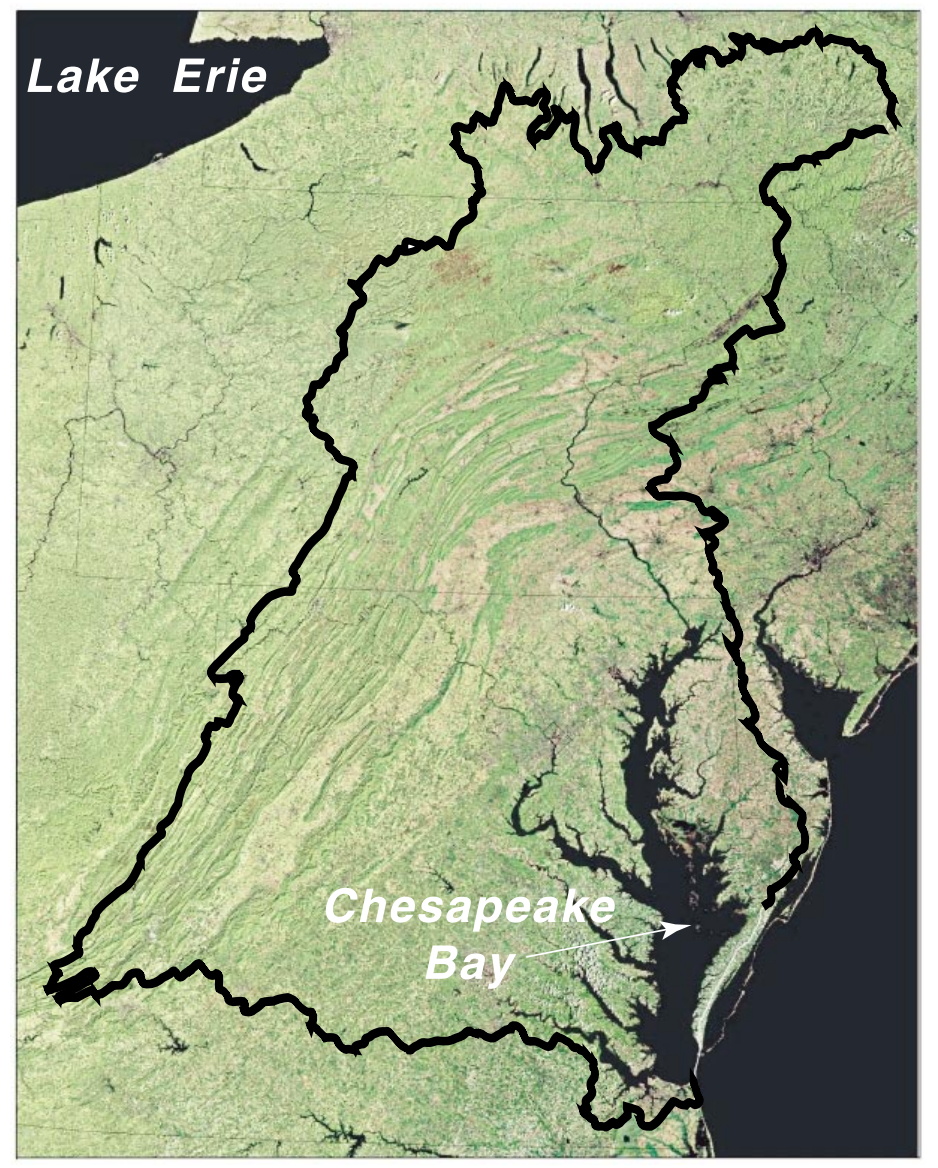

Figure 1. Satellite image mosaic of Chesapeake Bay and its watershed (outlined in black). The mosaic is composed of Landsat thematic mapper scenes collected in 1990-94. A poster of this image ("The Chesapeake Bay Watershed," 1997) is available from the U.S. Geological Survey; call 1-888-ASK-USGS.

\section{Methods to Understand the History of the Chesapeake Bay Ecosystem}

USGS researchers studying the Chesapeake Bay ecosystem have adopted a conceptual model linking the effects of natural climate variability (including rainfall, sedimentation, and sea-level rise) and human activities (including land clearance and fertilizer use) on the bay ecosystem (fig. 2). Both natural and human changes affect tributary discharge and nutrient transport to the bay, water clarity, salinity, habitat health and func- tioning, and living resources. The relationships among natural processes have been disturbed to an unknown degree by human activities in the watershed since European colonization in the 1600's. Although the bay's water quality, vital habitats, phytoplankton, and critical species have been monitored for the last 15 years, this interval is too brief to fully understand the bay's response to land clearance and urbanization of the last few centuries and to climatic extremes over decades to centuries. 


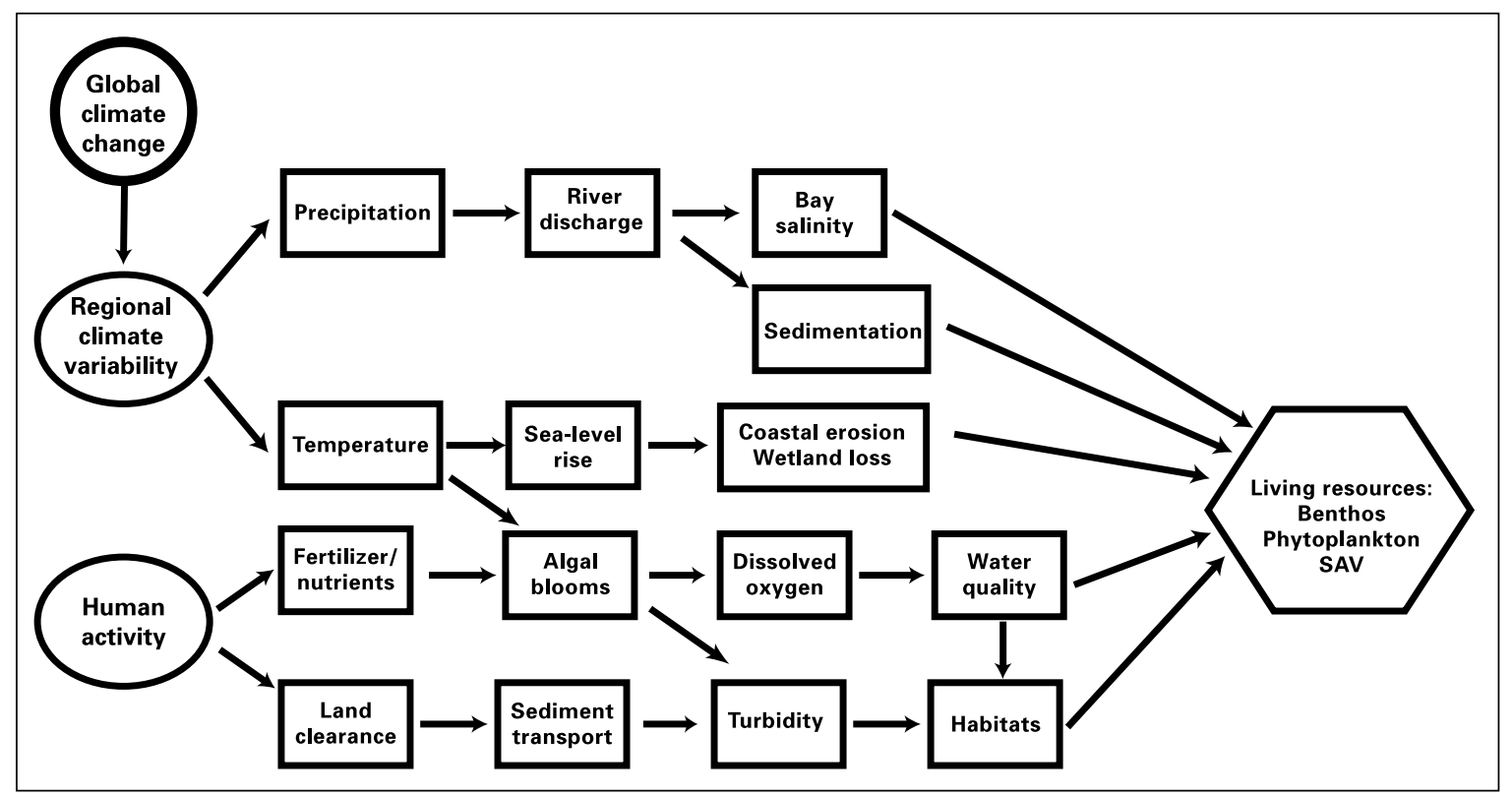

Figure 2. Integrated model of Chesapeake Bay, linking the effects of climate variability and human activities on the bay's ecosystem.

Sediments of Chesapeake Bay provide a rich archive of the bay's history, including its response to human events since early land clearance in the 1600's and to regional climatic shifts from droughts to intervals of heavy rainfall. Long-term records of water-quality parameters based on geochemical and paleoecological proxies (indicators) from sediment cores allow researchers to examine the impact of events on annual, decadal, and centennial scales and to predict how the bay will respond to future climate change and land-use practices.

\section{Collecting and Dating Sediments in Chesapeake Bay}

Through partnerships with the Maryland Geological Survey (MGS), the Naval Research Laboratory, and the U.S. Environmental Protection Agency, the USGS obtained sediment cores from several areas in Chesapeake Bay over the past few years. In 1996 and 1998, coring was carried out on board the MGS R/V Discovery, and additional coring took place in June 1999 on the French ship R/V Marion-Dufresne (fig. $3)$. The Marion-Dufresne coring produced the longest sediment cores yet recovered from the bay (17-20 meters), providing nearly complete records of the past 10,000 years of bay history and an exceptionally detailed record of the postcolonial period. X-radiographs and lithologic analyses of sediment cores reveal the variability in sedimentation caused by alternating periods of drought and wet climate and associated freshwater inflow from tributaries (fig. 4).

After sediment cores are photographed and described, the numerical ages of either the sediment or preserved fossil shells are determined by using isotopic dating methods. These methods include analysis of three radioisotopes:
${ }^{210} \mathrm{~Pb}$ (lead), which is ideal for dating sediments deposited over the last century; ${ }^{137} \mathrm{Cs}$ (cesium), which allows identification of sediments deposited since 1963; and ${ }^{14} \mathrm{C}$ (carbon), which is useful for dating material deposited as long as 40,000 years ago.

Isotopic dating of Chesapeake Bay sediments is supplemented by biostratigraphic analysis of fossil assemblages preserved in the sediments. Pollen pro-

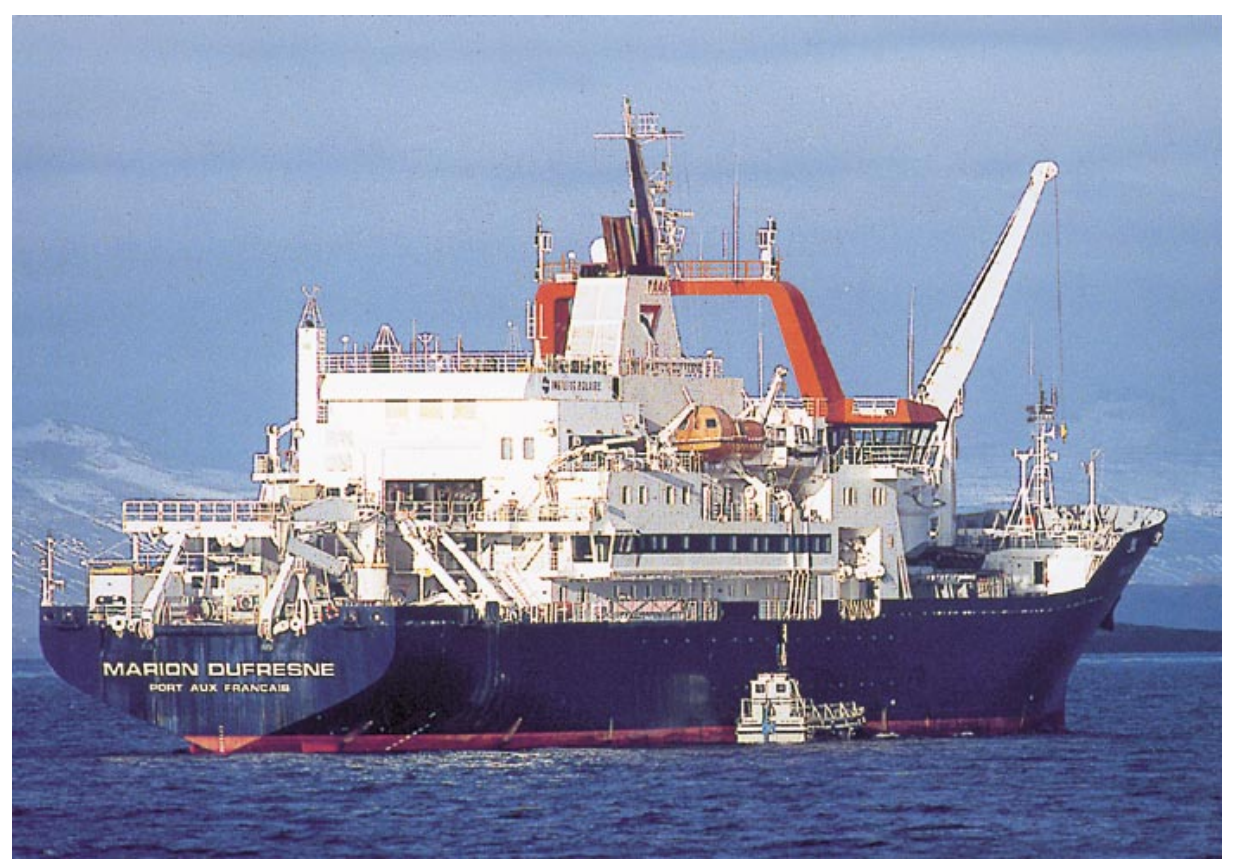

Figure 3. French research vessel Marion-Dufresne. Coring onboard the RN Marion-Dufresne during 1999 produced the longest sediment cores recovered from Chesapeake Bay. Photograph by F. Delbart of the Institut Français pour la Recherche et la Technologie Polaires. 
duced by plants growing in the watershed is deposited in bay sediments. Certain key pollen events, such as the sudden increase in ragweed pollen during the interval of maximum land clearance in the 1800 's, are well dated from historic and isotopic evidence. Also, the composition of benthic (bottom dwelling) communities has changed over the past thousand years, and the presence, absence, or change in abundance of species can be used to evaluate the age of sediments. Together, isotopic and biostratigraphic methods allow sediments to be dated within 10 years in regions of the bay where sediment has accumulated at rates of 0.5 to more than 3 centimeters per year.

\section{Indicators of Chesapeake Bay Habitats and Water Quality}

Biological (paleoecological) and geochemical indicators from Chesapeake Bay sediments record trends in salinity, temperature, oxygen, turbidity, and other vital habitat conditions. Salinity indicators, for example, are the fossil remains of species whose abundance in a benthic community changes in proportion to fluctuations in bay salinity. Indicators of reduced levels of dissolved oxygen (anoxia/hypoxia) include fossils of benthic species that live in waters with low levels of dissolved oxygen. Other species that are abundant during intervals of high turbidity can be used to document changes in water clarity. Preserved cysts of dinoflagellates and diatom valves provide records of phytoplankton abundance in the bay. Abundance trends in subaquatic vegetation (SAV), including sea grasses, are indicated by the fossil remains of organisms that live exclusively on SAV and fossil seeds from the SAV.

Geochemical proxies include indicators of dissolved-oxygen levels, such as nitrogen isotopes $\left({ }^{15} \mathrm{~N}\right)$, oxygen-sensitive metals, and silica produced by phytoplankton. Water temperature can be reconstructed from analysis of the chemical composition of shells of organisms such as mollusks or ostracodes. In sum, both biological and geochemical indicators provide consistent means of tracking changes in water quality and habitats and the response of bay communities during critical periods in bay history.

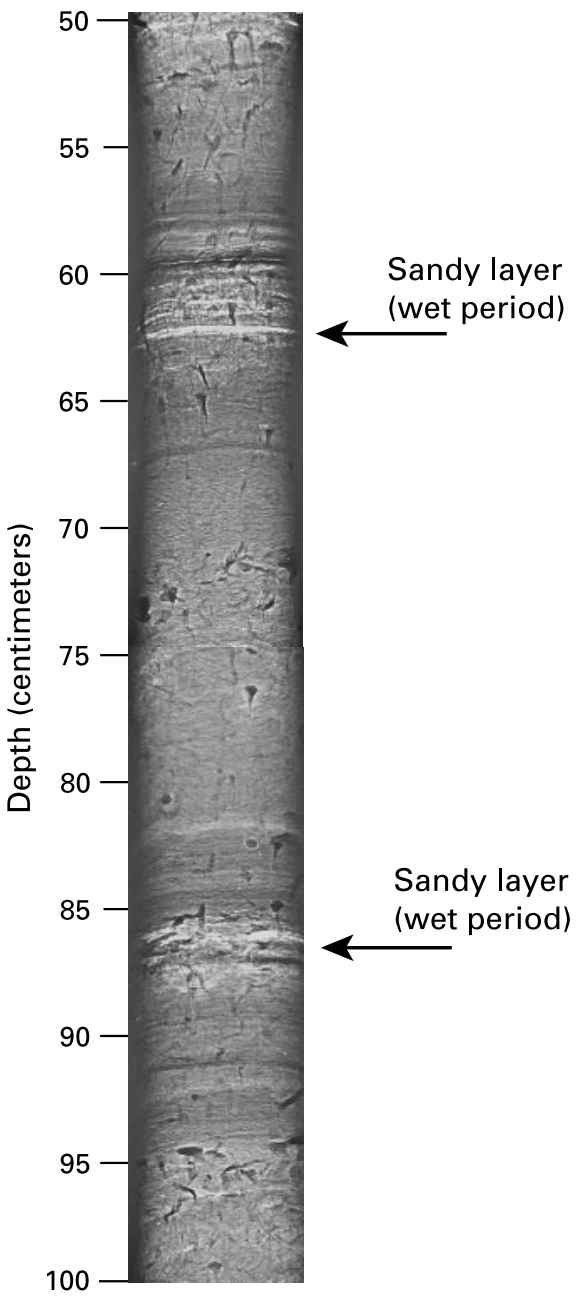

Figure 4. X-radiograph of Chesapeake Bay sediments from a core collected near the mouth of the Little Choptank River, showing sediment structures related to river discharge and climate.

\section{Chesapeake Bay and Water Quality}

\section{Effect of Climate Variability on Chesapeake Bay}

Climate variability affects the amount of rainfall in the mid-Atlantic region, which in turn affects the amount of freshwater entering the bay. Freshwater inflow influences bay salinity, nutrient loads, oxygen depletion, and water clarity. USGS researchers have documented the impact of natural climate variability on vegetation and sediment transport in the watershed and on water quality in the bay in sediment records covering the last few thousand years. For example, USGS research has identified 14 wet-dry cycles during the last 500 years, as recorded by fluctuations in salinity-sensitive benthic foraminifers (fig. 5). In the 16th century and the early 17 th century, "megadroughts" caused higher salinity in the bay, and these droughts exceeded those of the 20 th century in severity. Wet periods were shorter, with mean annual rainfall 25-30 percent greater and freshwater discharge $\sim 40-50$ percent greater than during droughts. A shift toward wetter regional climate also occurred in the early 19th century (fig. 5), lowering salinity and compounding the effects of agricultural land clearance on bay ecosystems. During the past 50 years, the region experienced a dry period in the 1960's; much wetter conditions began in the 1970's. Over the past 20 years, there has been high year-to-year variability relative to that of the past few centuries.

In addition to evidence for multidecadal (60-70 years) climate variability, there is evidence for shorter term climatic cycles lasting 3 to 15 years. Preliminary results suggest links to both the El Niño-Southern Oscillation and possi-

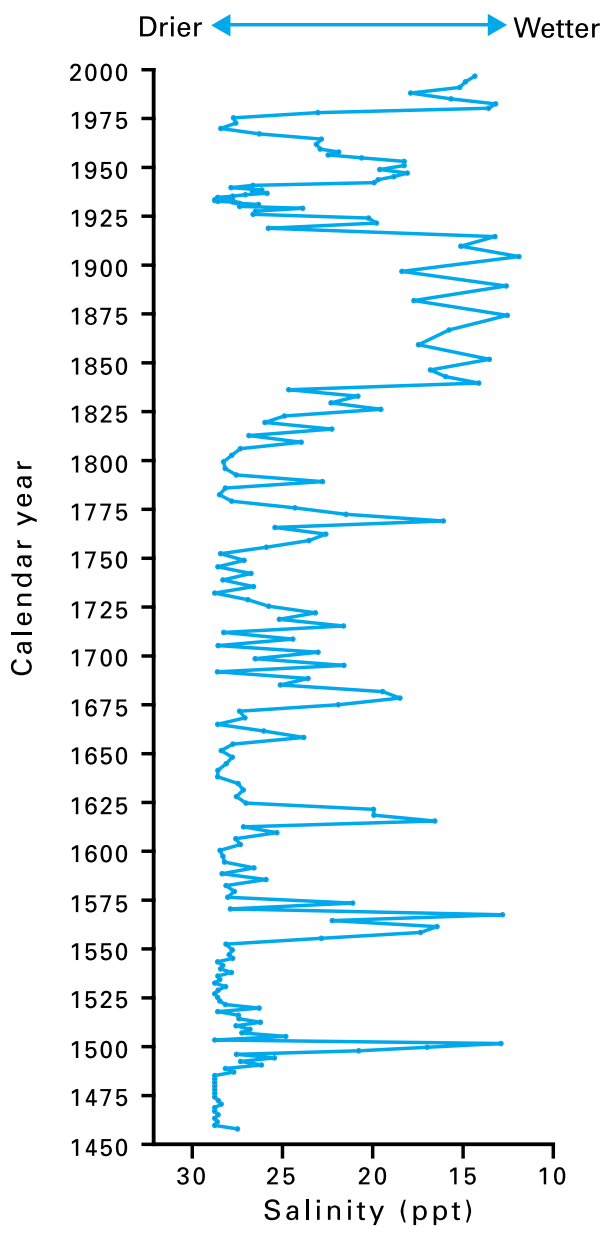

Figure 5. Salinity changes (in parts per thousand) off the mouth of the Patuxent River in Chesapeake Bay during the last 550 years. The salinity changes were interpreted from fluctuations in the abundance of benthic foraminifers in cores. 
Spiniferites mirabilis (percent)

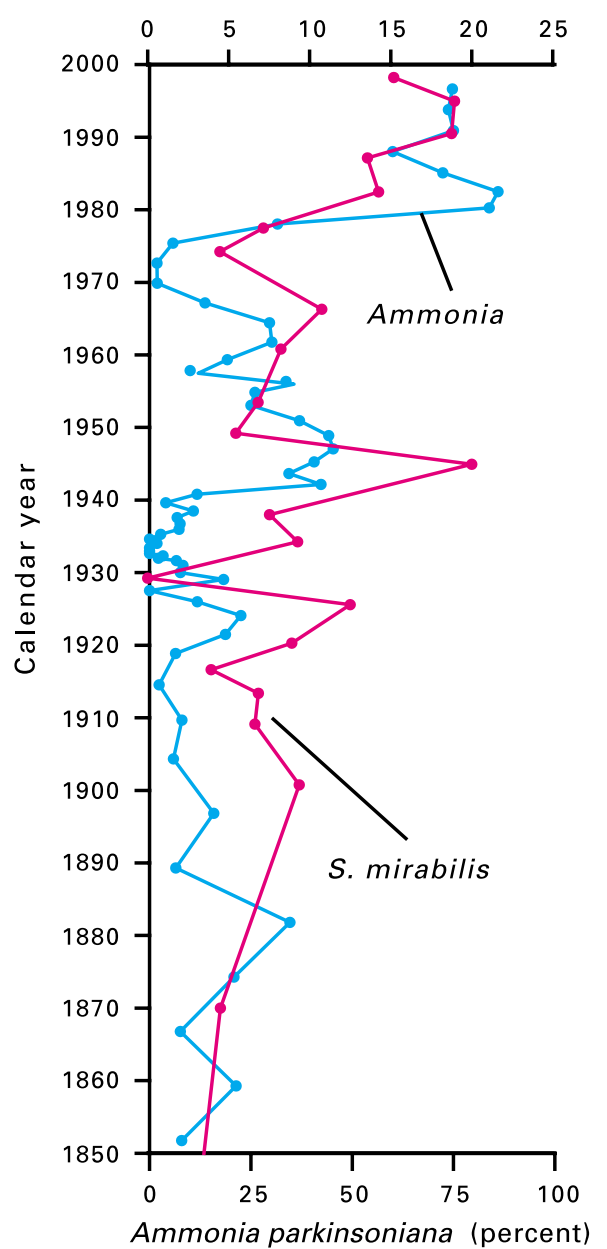

Figure 6. Abundance trends of two species tolerant of reduced oxygen levels, the foraminifer Ammonia parkinsoniana (blue) and the dinoflagellate Spiniferites mirabilis (red). Increased proportions indicate significant anoxia and hypoxia in the bay.

bly the North Atlantic Oscillation (7-14 years). Determining connections to these climate patterns would aid in efforts to predict future regional climate, rainfall, stream discharge, and water quality trends.

\section{Trends in Dissolved Oxygen}

Influxes of nutrients such as nitrogen and phosphorus can lead to blooms of algae (including toxic dinoflagellates) that block sunlight from bay grasses and deplete the water of oxygen needed by other organisms. By examining trends in benthic foraminifers and ostracodes, USGS researchers have esti- mated the severity of oxygen depletion and its impact on Chesapeake Bay benthos over the past few centuries. USGS studies show that, since the 1970's, the foraminiferal species Ammonia parkinsoniana, a species tolerant of reduced oxygen levels, has become the dominant species in many parts of the middle bay where oxygen depletion occurs. Moreover, there is strong evidence that anoxic and hypoxic conditions have been responsible for deformities in the shells of Ammonia living in Chesapeake Bay. Evidence indicates that oxygen depletion since the 1970's has been the most extensive of the past 500 years in the bay and the lower Potomac and Patuxent Rivers (fig. 6). This degradation in water quality is attributed to the combined effects of increased freshwater discharge since 1970 and increased nutrient influx, most likely from fertilizer application.

\section{Land Clearance, Water Quality, and Sedimentation}

Concern about the effect of sediment on water clarity and habitat requirements for SAV and concern about the potential release of sediment from Susquehanna River dams has led USGS scientists to reevaluate the relationships among land use, sedimentation, and water clarity in Chesapeake Bay. The vegetation history of the past 2,000 years and the effect of colonization on vegetation and sedimentation are recorded by pollen evidence from the middle bay (fig. 7). Pollen trends indicate a sharp rise in ragweed and grass pollen and a coincident decrease in oak pollen during the late 19th century. These trends reflect clearance of up to 80 percent of the forests in the watershed and parallel the rise in lumbering activity during that period. Field abandonment and forest recovery during the early

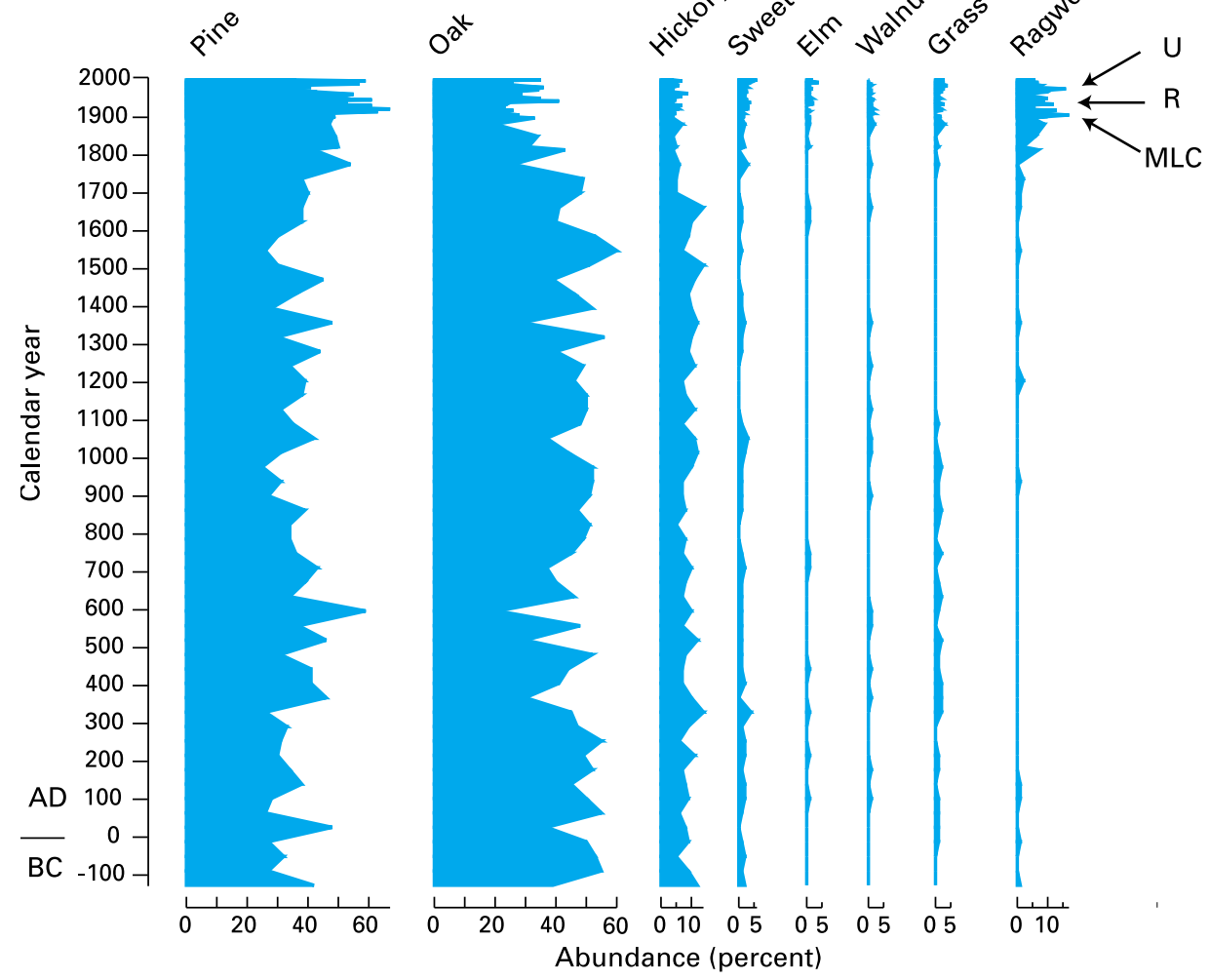

Figure 7. Abundance trends in pollen from major plants record 2,000 years of vegetation history in the Chesapeake Bay watershed. Major land-use changes are indicated by the changing abundance of ragweed pollen. $U$, urbanization; $R$, reforestation; MLC, maximum land clearance. 

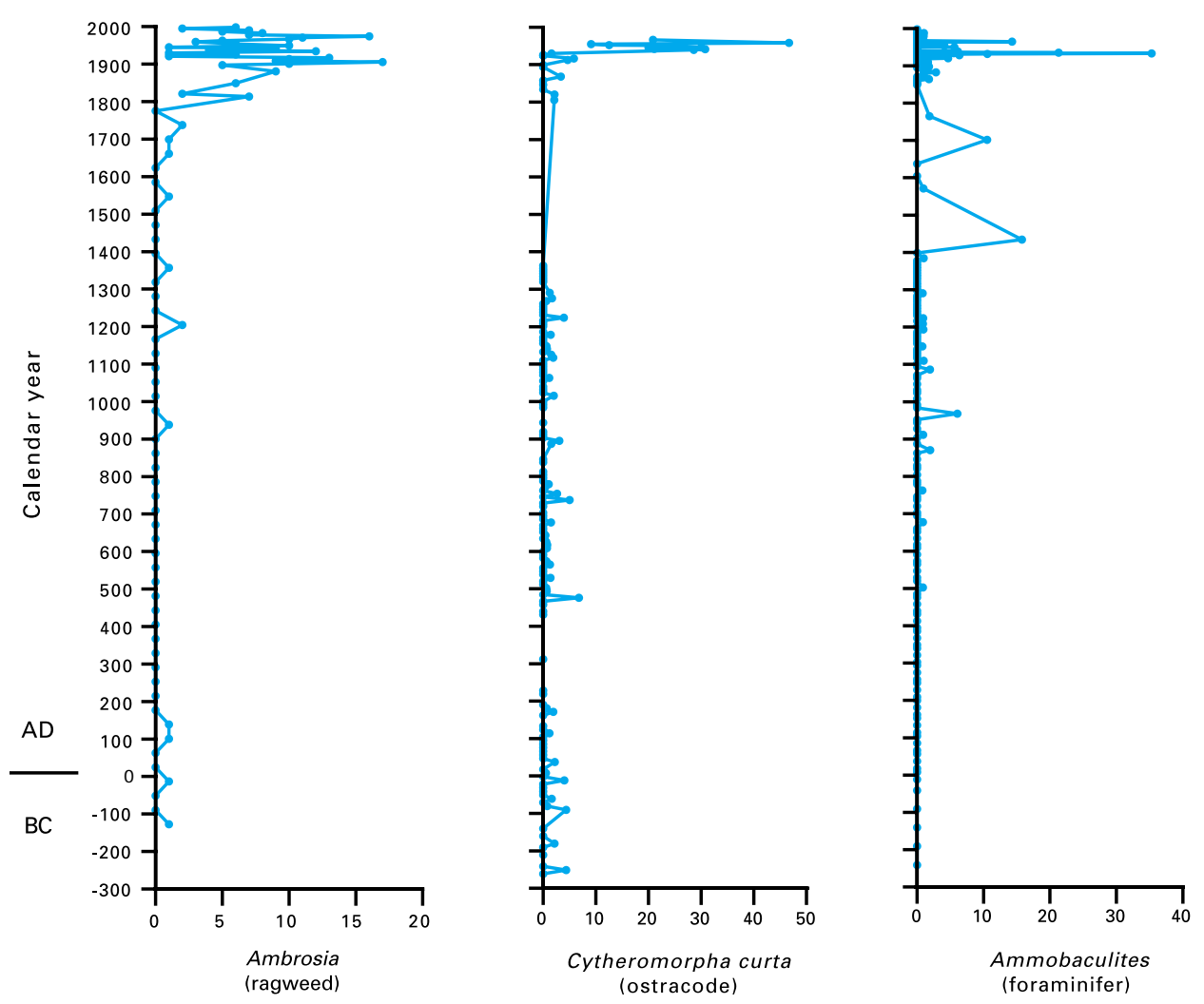

Figure 8. Changing abundances of benthic ostracodes and foraminifers tolerant of poor water clarity highlight the effect of 19th century land clearance on benthic faunas of Chesapeake Bay. Increased Ambrosia (ragweed) pollen abundance corresponds to periods of increased land clearance.

20th century are reflected by an increase in tree pollen and decrease in ragweed pollen. A second period of deforestation during urbanization in the 1950's and 1960's is recorded by another peak in ragweed pollen abundance.

Land clearance was especially severe during the 19th century, leading to a fourfold increase in sediment accumulation in the main channel of the middle bay over that during precolonial times. That increase had profound effects on bay biota, as some species disappeared entirely from the bay while others became dominant components of bay benthic and phytoplankton communities (fig. 8). For example, Cytheromorpha curta and Ammobaculites (ostracode and foraminifer taxa, respectively), organisms that inhabit turbid water, increased during the past two centuries. The effect of the degraded water clarity and quality in the last 150 years on phytoplankton is reflected in the increase in abundance of the dinoflagellate species
Spiniferites mirabilis (fig. 6). These paleoecological proxies indicate that water clarity during the late 19th century may have been worse than at any other time in the past few millennia. Continued high sediment influx has occurred throughout the 20th century, due to more mechanized techniques of land clearance, urbanization, and periods of high streamflow. Relative to precolonial times, water clarity in the bay remains degraded. More details of bay response to land use are now under investigation.

\section{Scientific Conclusions}

- A complex linkage exists between climate and land use in the watershed and water quality and habitat loss in Chesapeake Bay over the past few thousand years.

- Extended droughts have punctuated the history of Chesapeake Bay, sometimes lasting for decades and having severe impacts on the bay's planktic and benthic communities.
- Oxygen depletion has reached unprecedented severity since the 1970's due to greater freshwater runoff and nutrient influx.

- Turbidity and water clarity reached unprecedented degraded conditions during the late 1800 's. Slight improvements have occurred in the 20th century, but water clarity has still not returned to pre-land-clearance levels and exerts a significant influence on the benthos.

- If annual precipitation increases significantly, then it will likely have a negative effect on bay salinity, water clarity, and dissolved-oxygen levels.

\section{Implications for Chesapeake Bay Restoration}

Several recommendations emerge from these studies for future restoration and management efforts in Chesapeake Bay.

- Further work is necessary to establish the patterns of past change in rainfall and how resulting aquatic changes affected the bay's planktic and benthic communities.

- Modeling of various Chesapeake Bay parameters should take into account the likelihood that year-toyear and decadal extremes in climate variability and hydrology, including precipitation and freshwater runoff, may be greater in future decades than in the recent past.

- It is essential to better understand the causes of past climate variability and the connections between regional climate in the mid-Atlantic region and other regions, such the Pacific Ocean. Knowing these will help to design better restoration scenarios.

- Monitoring of Chesapeake Bay benthos should not be limited to macrofauna but should also include smaller organisms, such as ostracodes and foraminifers, that have been shown to be sensitive indicators of water quality, oxygen levels, and turbidity. 
- A better understanding of the sources of sediment and their relation to nutrients and water quality is needed to predict the effectiveness of land-use decisions.

- There is a need for more forested land cover and less sediment runoff. Additional study is needed of sedimentation and the response of living resources to turbidity, especially because sediment that has accumulated behind dams and in tributaries may eventually be released to the bay.

\section{Further Reading}

Cronin, T.M., Colman, S., Willard, D., Kerhin, R., Holmes, C., Karlsen, A., Ishman, S., and Bratton, J., 1999, Interdisciplinary environmental project probes Chesapeake Bay down to the core: Eos, Transactions of the American Geophysical Union, v. 80, no. 21 , p. $237,240-241$.

Printed on recycled paper
Cronin, T.M., Wagner, R.S., and Slattery, Moira, eds., 1999, Microfossils from Chesapeake Bay sediments; Illustrations and species database: U.S. Geological Survey Open-File Report 99-0045 (Also available online at http://pubs.usgs.gov/pdf/of/of9945/.)

Cronin, T.M., Willard, D.A., Karlsen, A., Ishman, S., Verardo, S., McGeehin, J., Kerhin, R., Holmes, C., Colman, S., and Zimmerman, A., 2000, Climatic variability in the Eastern United States over the past millennium from Chesapeake Bay sediments: Geology, v. 28, no. 1, p. 3-6.

Karlsen, A.W., Cronin, T.M., Ishman, S.E., Willard, D.A., Holmes, C.W., Marot, M., and Kerhin, R., 2000, Historical trends in Chesapeake Bay dissolved oxygen based on benthic Foraminifera from sediment cores: Estuaries, v. 24, no. 3.

\section{For further information contact:}

Thomas M. Cronin

Debra A. Willard

U.S. Geological Survey

926A National Center

Reston, VA 20192

E-mail: tcronin@usgs.gov dwillard@usgs.gov

Scott W. Phillips

U.S. Geological Survey

8987 Yellowbrick Road

Baltimore, MD 21237

E-mail: swphilli@usgs.gov

or visit the Chesapeake Bay Ecosystem History home page at http://geology.er.usgs.gov/eespteam/ches/ bayhome.html 